\title{
The understanding and the use of the term Allah as a term for God in translations of the Bible and the Qur'an with specific reference to the Talysh speakers of Azerbaijan
}

\author{
Author: \\ Roelie van der Spuy ${ }^{1,2,3}$

\begin{abstract}
Affiliations:
${ }^{1}$ Wycliffe Bible Translators,
\end{abstract} \\ South Africa \\ ${ }^{2}$ SIL International, \\ United States \\ ${ }^{3}$ School of Ancient Languages \\ and Text studies, North-West \\ University, Potchefstroom \\ Campus, South Africa

\section{Correspondence to:} \\ Roelie van der Spuy \\ Email: \\ roelof_van_der_spuy@sil.org

\section{Postal address:} \\ 234 Beyers Naude Street, \\ Potchefstroom 2531, \\ South Africa \\ Dates: \\ Received: 21 Oct. 2014 \\ Accepted: 22 June 2015 \\ Published: 21 Aug. 2015 \\ How to cite this article: \\ Van der Spuy, R., 2015, 'The \\ understanding and the use \\ of the term Allah as a term \\ for God in translations of \\ the Bible and the Qur'an \\ with specific reference \\ to the Talysh speakers of \\ Azerbaijan', In die Skriflig \\ 49(1), Art. \#1895, 6 pages. \\ http://dx.doi.org/10.4102/ \\ ids.v49i1.1895
}

Read online:

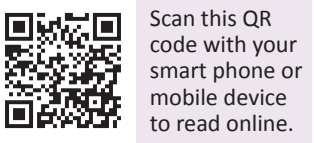

The term Allah is a term that quite often evokes strong negative emotions in the Western world. Since both the Bible and the Qur'an are being translated into Talysh, it is worth evaluating what term to use for God, and whether it would have a negative effect or not to use the term Allah in these translations. Suggestions are made from a Western point of view that Tanr, a Turkish term for God, would be a better term to use than Allah, as the term for the word God in translations of the Bible. The Qur'an as well as some Bible translations use the term Allah, which is one of the most common terms for God in the greater Turkic-speaking world in several languages. Should the Talysh Bible translation follow suit to make the translation culturally more acceptable?

Die verstaan en die gebruik van die term Allah as ' $n$ term vir God in Bybel- en die Koranvertalings, met spesifieke verwysing na die Talysh sprekers in Azerbaijan. Die term Allah is een wat altyd baie sterk negatiewe emosies uitlok in the Westerse wêreld. Aangesien die Bybel sowel as die Koran op die oomblik in Talysh vertaal word, is dit betekenisvol om te evalueer watter term vir God gebruik moet word, en of die gebruik van die term Allah enige negatiewe uitwerking op die vertalings sal hê aldan nie. Sekere mense vanuit ' $n$ Westerse wêreldbeskouing reken dat dit meer aanvaarbaar sal wees om die term Tanr in Bybelvertalings te gebruik as die term Allah. Die Koran sowel as sekere Bybelvertalings in die groter Turks-sprekende area gebruik die term Allah. Allah is een van die mees algemene terme vir God in verskeie tale in daardie area. Moet die Talysh Bybelvertaling ook die voorbeeld navolg en Allah in hulle vertaling gebruik om dit kultureel meer aanvaarbaar te maak of nie?

\section{Introduction}

Will it be beneficial to use the term Allah as the translation of the terms elohim/theos in the Bible translation for Talysh speakers? If the term Allah is used, it could make the Bible a less foreign book to Talysh speakers. Would it, however, be acceptable to use the term Allah in a Bible translation at all?

Interest in this topic was sparked by the usage of the word Allah in the Talysh 'interpretation' [translation] of the Talysh Qur'an, which is a language from the Iranian language family and Allah being a transliteration of the Arabic term for God (Naude 1971:33). Both the Qur'an and the Bible are now being translated into Talysh. In the Talysh version of the Qur'an the most commonly used term for God is Allah, but in the Talysh translation of the Bible a debate commenced whether Allah or Xıdo (the most common Iranian based term for God) should be the translation for elohim and theos. Would it make the Talysh Bible translation more accessible if the term Allah is used rather than $\mathrm{X} \imath$ do?

In this article I would like to reach an understanding of what the most basic terms for God are amongst the Talysh speakers of Azerbaijan. Since the term Allah is used in the Talysh Quran, what would be their common understanding of the term Allah, and what feeling is conveyed by the word Allah to members of this Iranian-language group of people. Is it at all acceptable to use the term Allah in a Bible Translation?

Copyright: (c) 2015. The Authors. Licensee: AOSIS OpenJournals. This work is licensed under the Creative Commons Attribution License. 
The term Allah has been used by several other Bible translations ${ }^{1}$ in a predominant Turkic speaking Muslim context, as for instance in the Tatar ${ }^{2}, \mathrm{Kumyk}^{3}$ and Azerbaijani Bible $^{4}$ translations.

\section{Method, location, target group and language of survey}

Because of the situation's sensitivity I could not personally interview the respondents. Political, religious and personal circumstances prohibited me from doing the research myself. The result was a small preliminary survey amongst people we could reach, rather than a full-fledged random survey.

I made use of the help of four Talysh speakers to assist me with the survey. Twenty-six questionnaires were completed with the help of four Talysh speakers. Three of the interviewers were ladies. Two of them are in their fifties, and one lady was still in her twenties. The one male interviewer is also in his fifties.

Although I could not do the survey myself, I reviewed the results with the interviewers as they were completing the questionnaires. After the first few responses were received, I realised that we did not obtain enough insights into some of the aspects I envisioned obtaining. We adjusted the questionnaires and added some indirect questions about the understanding and also the usage of the word for God in other situations. Such questions as 'How well is the word Xido or Allah known?', 'What other terms for God are commonly used?' as well as questions about how they refer to God in curses and blessings, were added or rephrased to get more insight into the differences in the usage.

The Talysh language belongs to the Iranian language family (Stilo 1981). The majority of Talysh speakers are living in Azerbaijan where Azerbaijani a Turkic language and the national language, is used in schools and universities. Many Talysh people are not fluent in reading their own language. Thus, Azerbaijani was chosen as the language of the questionnaire, quoting Talysh words, terms and phrases, with a glossary in English to make the data more accessible to other researchers. The interviews were mostly done in both Talysh and Azerbaijani. About a third of the respondents lived in cities, whereas the rest were from the motherland of the Talysh group - the border area between southern Azerbaijan and northern Iran. This survey was done in the Azerbaijani area, but included respondents who were residents from both sides of the border.

\footnotetext{
1.From the IBT Moscow Website (viewed 10 October 2013 , from http://ibt.org.ru/ english/bible/ttr.htm) is it clear that quite a few Bible translations are using Allah as the most common word for God, for instance in Genesis 2:8. It means that the word Elohim is translated as Allah. A few translations from the Turkic language family are using the Iranian based word for God. Kazak and Karakalpak use Xudai IYI and Turkmen uses Beyik Huday

2.Tatar uses the term Раббы Алла - Rebb Allah http://ibt.org.ru/english/bible/ttr.htm

3.Kumyk uses Раббибиз Аллагь - Rebb Allah http://ibt.org.ru/en/text.htm?m= KUMYK\&I=Gen.2.1.1\&g=0

4.Azerbaijani uses the same two terms - Rabb Allah http://ibt.org.ru/en/text.htm?m= AZE\&I=Gen.2.1.1\&g=0\#sv
}

\section{Ethnographic and religious background}

The Talysh language is spoken by just under a million people (Lewis, Simons \& Fennig 2015). Although most are living in southern Azerbaijan and the northern areas of Iran, there are also pockets of Talysh speakers around Moscow and smaller communities spread out all over the globe.

The Talysh are 99\% Muslim with a very small number of Christians. The Christian population is less than $1 \%$. Traditionally, the religion of Zoroastrianism was prevalent amongst them. Some would still profess to be Zoroastrians who have now become Muslims. The area where they live has considerable oil and gas reserves, and there are places where there are the so-called eternal burning flames - thus, explaining the traditional inclination to Zoroastrianism. No one confessed to still adhere to Zoroastrianism. Less than a third of the respondents, eight to be exact, were from a Christian background whereas the 18 remaining interviewees were from a Muslim background.

\section{Survey}

A few introductory remarks on this topic are necessary: Firstly, what are the influences that play a role in choosing a term for the translation of elhohim or theos? For instance, is the most common term for God to be chosen or instead a term that is known in another well-known holy book or books from that region?

Secondly, if a specific term is preferred above another, what is the reason for choosing that term? Is it merely the most used term or does that choice reveal an underlying prejudice of the translators for or against a certain influence or religion? Or is the term neutral?

Thirdly, closely related to this, what is the connotation ascribed to this chosen term for God by the target readers? How will that term be received by the people in the target context? Will it make a positive contribution so that people would desire to read the translation, or will it be a stumbling block for reading the translation?

In Muslim circles there is a tendency to use the transliterated Arabic form of the word for God, namely Allah in all 'translations' of the Muslim Holy Scriptures, the Qur'an ${ }^{5}$ as well as in secular domains (Ahmed 2011). In many Western Christian circles there is a tendency to shy away from the usage of the transliterated word Allah in translations of the Bible and in any religious context, because the transliterated word for God, namely Allah is seen as the name of the Muslim God. 'It is inconceivable to many that a word that is commonly associated with the Islamic religion would be found in a Christian Bible' (Thomas 2001:301).

5.Talysh Qur'an viewed 16 March from www.talysh.com (this website has been discontinued and migrated to Facebook, viewed 04 June 2014, from https:// www.facebook.com/groups/370348646312114/permalink/582199931793650/) www.facebook.com/groups/370348646312114/permalink/582199931793650/).
Another proof of this well-known fact is, from http://quran.com/3 (viewed Another proof of
23 February 2015). 
TABLE 1: Terms for God.

\begin{tabular}{lccc}
\hline Talysh terms for God & Total & Muslim respondents & Christian respondents \\
\hline Xıdo & 26 & 15 & 8 \\
Ilahi & 9 & 6 & 3 \\
Allah & 7 & 4 & 3 \\
Xəlləği-Aləm & 13 & 6 & 7 \\
Xıdovandi-Aləm & 8 & 5 & 3 \\
Tanrı & 1 & - & 1 \\
\hline
\end{tabular}

Therefore, the word Tanr (the Turkish variant of the term God, related to the term Tengri) is quite often preferred by missionaries $^{6}$ and others (Ruben 2006:149) ${ }^{7}$ from the West above the form Allah, because they feel that Tanr is a more neutral term for God. This tendency led me to also include a few questions about the understanding of the word Tanrı. I added a few references to Tanrl, trying to determine whether the term Tanr would be a more acceptable, neutral choice in a translation of the Bible and how this term would be understood and evaluated - both by respondents from a Christian as well as a Muslim background in the Azerbaijani context.

\section{Their term for God}

The first question I would like to analyse regarding how the Talysh speak to God and about God is: 'How do you as a Talysh speaker address God?' Further we are analysing the question, 'What words do the Talysh people use for God?' The following question provided an interesting result: 'What do you call God in prayer?' The responses to these questions were grouped together, and therefore the numbers did not always add up to 26 - the number of respondents.

All Talysh speakers call God, amongst other variants, Xıdo [Khido] - the Iranian based term for God. However, when we asked how they personally addressed God in prayer, one respondent mentioned only Allah. See Table 1.

From this table $\mathrm{e}^{8}$ it is obvious that $100 \%$ of the respondents from this Iranian language family use the term Xıdo for God. Looking at the other terms for God that are used, XalloğiAlam [The Almighty - The Owner of the universe] was the second most frequently used term. Allah was fairly low down the list. It is interesting that the same tendency is seen amongst the Muslim as well as the Christian respondents. Only one Talysh speaker mentioned that, when he addressed God in prayer, he only used the word Allah. The only respondent who mentioned Tanr as a term she, as a Talysh speaker used, is from the Word of Life Church where they were asked to use Tanr rather than Allah in the Azerbaijani speaking church. She then transferred this usage also when speaking Talysh.

6.Word of Life Church, Azerbaijan instructed their members to read Tanrı where the word Allah appears in the Azerbaijani Bible translation (viewed 04 June 2014, from http://wol.az/).

7.It appeared in footnote 19 of the citation.

8.The survey numbers do not always add up exactly, because some respondents did not answer all the questions and sometimes some of them gave more than one answer to certain questions.

\section{The usage of terms for God in blessings and curses}

Since blessings are a very integrated part of everyday life in the Caucuses and Iran, we added questions, which were not directly focussed on the terms for God as a verifying device. These questions focussed on the function of blessings and curses in their society. We asked what blessings and/ or curses they use in certain situations, for example, when congratulating somebody or when someone was ill. This was done in order to see what form of the word for God Talysh speakers use in these situations. By asking them to provide commonly used blessings, we tried to divert their attention away from the questions about which word they use when referring to God.

In all the examples of curses and blessings that were given by the respondents, the word X 1 do was used in more than $90 \%$ of the cases by those who answered the question. More than half of the respondents did not answer the question. From the remaining 12 responses, 11 used Xıdo in the blessings and only one respondent indicated that he uses Allah in blessings. That could most probably be because he is a very devout Muslim, who prefers to use Allah in all religious contexts. This is similar to the findings by John Morrow (2006:40) where they indicate that Persian speaking people would use $X \imath d o$ in everyday language, but Allah in religious contexts. This reinforced the information that was gathered from the question of addressing God in prayer that both Muslim and Christian Talysh people prefer to use the term Xıdo.

\section{How is the word Allah understood?}

In order to clarify this question we added a question like, 'What does the usage of the word Allah convey in your context?' According to most respondents the word Allah just means God, Creator God.

Not a single respondent indicated that this word reminded them in any way that this is a term used only by Muslims to address their God. The questions regarding Allah were answered in a totally neutral manner, just indicating that this term for God indicates that God is the Creator or the High God, the Almighty. In the indirect verifying questions, again referring to the word Allah amongst other words for God, once again a unanimous response indicated that there is absolutely no negative or Muslim connotation to the usage of this term for God amongst the Talysh speakers in Azerbaijan. It is interesting that only seven of these 26 Talysh-speaking respondents mentioned Allah as one of the options of how they address God in prayers, four of them were Muslim and three were Christian. Keeping in mind that $X \imath$ do is the Iranian language based term for God, it is interesting that one respondent mentioned that he only addresses God as Allah when praying. That is the same person that also only used Allah in blessings.

In order not to only focus on the word Allah, a few questions referring to other terms for God were included in the questionnaire. One of these questions asked was, 'What 
TABLE 2: Meaning of the term Allah.

\begin{tabular}{lcc}
\hline Meaning of the word Allah & Muslim responses & Christian responses \\
\hline Creator & 4 & 4 \\
Saviour & 2 & 3 \\
Provider of everything & 3 & 4 \\
Judge & 2 & 3 \\
God in Spirit & 2 & 1 \\
Heavenly Father & 1 & - \\
The Almighty One & 2 & - \\
King & 1 & - \\
\hline
\end{tabular}

are the meanings of the following terms, and who would use them?' There were no suggested answers provided. The terms we referred to were Parvordigar, Tanr and Allah. Only the responses ${ }^{9}$ regarding the word Allah are tabled in Table 2.

A strong feeling exists in the West that the word Allah is only associated with Islam. This research has proven that there is no bias or special affinity towards Islam amongst the ordinary people in the Talysh speaking world as there exists in the West when the term Allah is used - even though Allah is not the original or most used term for God amongst these speakers belonging to this Iranian language family. The term Allah has been adopted as just another word for God alongside Xıdo, Ilahi, and for a minority, Tanrı.

\section{The western affinities for using Tanri as a 'neutral' term for God in Christian communities}

On the other hand, the term Tanrl, as seen by some people in the West as a more neutral term, seems to carry more negative connotations than the term Allah. The other terms mentioned for God do not carry any of these negative connotations for the Talysh speaking people. Therefore, I conclude that it would be better to use the word Allah rather than Tanr, if $X \imath$ do is not used.

This brings us to the next question: Why would the Talysh translators of the Qur'an use Allah as their most common term for God and not Xıdo, whilst the Bible translators never use Allah?

As mentioned above, in the West it is quite often felt that Bible translations in the Muslim dominated parts of the world should not use Allah, but rather use Tanrı as a neutral alternative.

In an interview with a local Christian believer, she confirmed that certain local Christian groups are insisting that Tanr is used instead of Allah. Even when reading from the current Azerbaijani Bible translation where the term Allah is used for God, they read Tanr. Most local believers have no problem

9.Just a note about the calculation of the survey numbers: Sometimes respondents would give a response to only one of the three terms for God, but others gave more would give a response to only one of the three terms for God, but others gave more
than one response per question. Therefore, the numbers do not always balance than one re
exactly.
TABLE 3: Responses regarding the word Tanrı.

\begin{tabular}{lc}
\hline Responses & Number \\
\hline Who is Tanrı? & - \\
Tanrı is the God of Zoroastrianism & 2 \\
Tanrı is an idol god & 3 \\
Tanrı is the God of the Turkish people & 4 \\
Neutral feeling about the term Tanrı & 11 \\
Total amount of responses & 20 \\
Did not answer - probably knew too little about the term Tanrı & 9 \\
\hline
\end{tabular}

using the word Allah in worshipping God. That fellowship uses Tanr, because the Western missionaries who founded the fellowship insisted that the word Allah should be replaced by the word Tanr in all instances. In the mind of the believer who was interviewed, there was no emotional difference between the two terms. She explained that the Muslims only use Allah, and Christians sometimes use Allah and sometimes Tanrı.

Not many respondents who were included in the survey, actually knew the term Tanri. One of the more welleducated respondents answered the question, 'What is the meaning of the terms Allah, Parvardigar (a term for God from Zoroastrianism) and Tanrt?', as follows:
Allah -
The Arabic term for God
Tanrt -
The Turkish term for God
Parvardigar - The Iranian term for God

From the survey it was clear that the majority of respondents did not have any feelings about using one of these terms, because it might convey a Muslim prejudice. Actually, a number of respondents, both Christians and Muslims, did not know the term Tanr.

The strongest trend I could detect was that some respondents felt that the word Tanr firstly referred to an idol god, not the Creator, Saviour or real God. Secondly, some respondents felt that if Tanr were used in a Talysh language translation, it would rather refer to the God of the Turkish people. Twenty respondents answered the question about who Tanr was. Nine of them, that is $45 \%$, had a non-neutral understanding of who Tanrt is. They were thinking that this term points to an idol god or the Turkish God. Nobody indicated that the term Allah refers to a pagan, idol or Muslim god.

Responses regarding the word Tanr are tabled in Table 3.

Thus, by using Tanr instead of Allah in a translation of the Holy Scriptures in the Azerbaijan area, one would actually not make the concept neutral; one would skew it.

Because we wanted to verify the information and cross-check the respondents answers, there was more than one question about the different terms for God. Information about Tanr was asked in three different ways. Therefore, we have more responses than the number of respondents. 


\section{The inclusion of the word Allah in Talysh Holy Scriptures}

What would the perceived benefits be of using the transliterated form of the Arabic word for God, namely Allah, in a Bible translation? Would it indicate an unspoken underlying implication that this God is the God of the Muslims or would it make the translation culturally more acceptable?

Certainly in the West, when speaking English, the transliterated form of the word for the Arabic term for God carries an emotional bias indicating that they are different (Morrow 2006:213) and that they are speaking about the God of the Muslims. This is clearly seen in articles like those on Kenneth J. Thomas (2001). D. Soesilo (2001) highlighted the same topic.

Another reference from the Asian world indicates that Christians and Hindus do not want to use the word Allah due to negative connotations to it. They preferred the Iranian based term Khuda. Interestingly, when the Bible was published, the believers from Muslim background insisted on a change. They did not want the Iranian based term Khuda, but they preferred the Arabic based word Allah! (King \& McCormick 2013:338)

In Malaysia we actually have the opposite problem. Campbell and Charlie (2013:1) state that a court prohibited Christians from using the word Allah in their publications. He then quoted the reaction of a Catholic father: 'Rev. Lawrence Andrew said he was "disappointed and dismayed".' Since the word Allah is so commonly used, the Christians are using it as the most common word for God without any other emotional strings attached.

Since the courts prohibited Christians from using the word Allah, they appealed, because they prefer using the term Allah. They claimed that there would be disharmony between Christians and Muslims if Christians now have to speak about God, using a different term. 'Few question whether Allah is the God of the Bible-to Malaysian Christians, Allah is simply the word for God' (Wunderink 2009:15).

In the West when the word Allah is transliterated and not translated, we move to what Grice (1975) and later Blakemore (1995:57) are calling Implicatures: 'Implicatures are assumptions derived from the proposition that the hearer takes the speaker to have expressed together with the context.' Thus, using certain well-understood terms in a specific proposition in a certain context, the speaker then actually implies something more. A common example would be if a guest says: 'He has an interesting hairstyle.' That speaker implied that the hairstyle of the person is out of the ordinary; in other words, something strange to look at.

In our discussion, the proposition focuses on one word: the transliterated form of the word for God, namely Allah. Therefore, I referred above to the usage of the transliterated word Allah, especially in the West. It seems as if these speakers might have a hidden agenda, as though they want to imply something more without saying it in so many words. They are saying more than what that single word expresses. By not translating the word Allah to God, an implicit message (that is not made explicit) is conveyed. An utterance implies more than the sum of the words.

It is my opinion that in the West, when Muslims do not translate the word for God, but use the transliterated form Allah, they actually would like to indicate that Allah is the God. Allah is their God, and they are different from the people around them - an opinion that can also be found in Morrow (2006:213).

This, however, does not necessarily seem to be the case in the Middle-Eastern Turkic and Iranian speaking world. There, the same proposition in another context implies something totally different. Our survey indicated a very neutral understanding of the word Allah.

This begs Western critics not to look at all the instances of the word Allah's usage as being the same or carrying the same meaning, emotional baggage or implying the same implicit message. Context plays a very important role in the understanding and consequent usage of the word Allah.

Certain further concepts from the so-called 'Relevance theory' of communication are applicable here. Since we do not communicate our intentions or meaning fully, we rely on the inferences that are activated by an ostensive (deliberate) stimulus that we give. A communicative stimulus is normally intended to steer the thoughts of the audience in a certain direction (Sperber \& Wilson 1992:60). Such an ostensive stimulus can have a greater or lesser impact. If the information in the stimulus is exactly the same as the context, the receiver of the stimulus will not process it, because it does not need processing. If the stimulus is different, then the receiver will infer the meaning and change will take place, but only if the stimulus is not too different, too foreign or too irrelevant. If the stimulus is different and relevant, then the receiver will infer what it communicates and change will take place.

In the context of the use of the transliterated word Allah, similar communication processes take place. If the word Allah is used deliberately or ostensibly, whilst bringing no new information to the already known context, there would be no change or reaction to that stimulus. If the stimulus were different, however, it would communicate something that would be inferred by the audience, listeners or readers. This inference will be based on their known context and their understanding of that stimulus. Thus, if the word Allah is used for God in the Talysh speaking world, it does not bring any new information to the known context and no change is inferred. When the word Allah is used in a Western context, however, it is different from the known contextual term for God and therefore change is introduced. The relevant context that the addressee is using for processing the new stimulus, is their knowledge and experience of Muslims; a 
context of Muslim extremism that would like to conquer the world, both in a military as well as a religious sense (whether this is a reflection of the truth about Muslims or not). The term Allah is used ostensibly and it draws attention to that proposition.

The biggest problem we have is that a stimulus in a MiddleEastern Iranian context cannot be read with glasses from the West and make relevant inferences that are appropriate for a context that is not known to you.

Therefore, just using the word Allah in a Western context is already an ostensive communication act, even without making the implicature manifest or overt. In a situation like that, the ostensive act of using the word Allah focuses the attention of the audience on their relevant reference framework, and thus contribute to the fulfilment of the informative intention relevant to the hearers (Sperber \& Wilson 1992:60).

I would say that in spite of the neutral feeling amongst the Talysh about the word Allah that the respondents indicated, there is an underlying mutual contextual knowledge that Muslims would prefer using the word Allah for God.

Therefore, when the translators of the Qur'an use the term Allah, they show their allegiance (which is then an act of ostensive communication to point the audience in a certain direction), and when the Bible translators use Xıdo [the most common used word for God], they use a more neutral term; a term that originated from the pre-Islamic Persian culture, which indicate their allegiance less overtly.

To conclude: the usage of Xido in a translation of the Holy Scriptures in a Talysh society is neutral, because it does not add new information to the known context. The usage of the word Allah can, as indicated by all of the Talysh speaking respondents, be neutral, but from the perspective of the translators, it can also be an implicature with the intention of allying God with the God of Islam. It is my impression that this is the case with the translation of the Qur'an in Talysh, where Allah is used as the most common word for God above Xido.

This conclusion is in line with what Ahmed (2011:146) found in his article. He concluded that the usage of the transliterated word Allah indicates an allegiance with Islam. However, it may be subtle for some readers, but the very fact that it is transliterated rather than translated already shows an allegiance. What Blakemore (1995) describes in the paragraph in the beginning of her discussion about implicatures sums up the situation with regards to the use of the word Allah very well:

A single utterance conveys a variety of assumptions. Some may have been specifically intended by the speaker. Others may fall within a wide range of assumptions intended by the speaker. In some cases the speaker's intention is overt, in others it is covert, and in others an assumption is conveyed completely by accident. (p. 57)

\section{Conclusion}

Western affinities, understanding and emotional connotations about the word Allah are different from those of the Talysh people. Although both Muslim as well as Christian Talyshspeaking people, whose language is from the Iranian language family nested in the Turkic world, use the word Allah normally in a neutral way, they do have a preference for their own Iranian based term, $X \imath$ do.

It seems obvious that the word Allah cannot be used in the West in a neutral way, but the opposite is true in the Talysh area, and neighbouring Turkic speaking areas. The word Allah can be used in a neutral way, as Wunderink (2009:15) confirmed: 'Few question whether Allah is the God of the Bible - to Malaysian Christians, Allah is simply the word for God.' Therefore, the Talysh Bible translation could use the word Allah without introducing any negative connotations. That might even have made the translation culturally more acceptable to the non-believing countrymen.

As a result, critics from the West should be careful not to make a negative evaluation about the usage of the word Allah before they grasped the context and understanding of the local culture.

\section{Acknowledgements Competing interests}

The author declares that he has no financial or personal relationship(s) that may have inappropriately influenced him in writing this article.

\section{References}

Ahmed, A.A.A., 2011, 'Translation versus transliteration of religious terms in contemporary Islamic discourse in western communities', International Journal of English Linguistics 1(2), 141-147.

Blakemore, D., 1995, Understanding utterances. An Introduction to Pragmatic, Blackwell Printers, Oxford.

Campbell, C., 2013, 'Allah means god, unless you're a Christian in Malaysia', Time. Com 10(16), 1-2.

Grice, H.P., 1975, 'Logic and Conversation', in P. Cole \& J. Morgan (eds.), Syntax and semantics 3: Speech acts, pp. 41-58, University College of London, Elsevier.

King, G. \& McCormick, T., 2013, 'Muslim idiom translations in Bangladesh', Evangelica Review of Theology 37(4), 335-348.

Lewis, M.P., Simons, G.F. \& Fennig, C.D. (eds.), 2015, Ethnologue: Languages of the World, 18th edn., SIL International, Dallas, TX, viewed 20 October 2013, from http://www.ethnologue.com/language/tly.

Morrow, J. (ed.), 2006, Arabic, Islam and the Allah Lexicon: How language shapes our conception of God, Edwin Meilen Press, Lewiston.

Naude, J.A., 1971, 'The name Allah', D.Litt. dissertation, University of Pretoria.

Ruben, B. (ed.), 2006, Religion and politics in Turkey, Routledge, London.

Soesilo, D., 2001, 'Translating the names of God: Experience from Indonesia and Malaysia', The Bible Translator: Practical Papers 52(4), 414-423.

Sperber, D. \& Wilson, D., 1995, Relevance: Communication and cognition, 2nd edn., Blackwell, Oxford.

Stilo, D.L., 1981, 'The Tati language group in the sociolinguistic context of Northwestern Iran and Transcaucasia', Iranian Studies 14(3\&4), 137-187. http:// dx.doi.org/10.1080/00210868108701585

Thomas, K.J., 2001, 'Allah in Translations of the Bible', The Bible Translator: Technical Papers 52(3), 171-174.

Wunderink, S., 2009, 'What's in a Name?', Christianity Today, August, pp. 15-16. 